\title{
Poly[N-(2-aminoethyl)ethyleneimine] as a New Non-Viral Gene Delivery Carrier: The Effect of Two Protonatable Nitrogens in the Monomer Unit on Gene Delivery Efficiency
}

Yahya Khazaie, ${ }^{1,2}$ Luis Novo, ${ }^{1}$ Ethlinn van Gaal, ${ }^{1}$ Afshin Fassihi, ${ }^{3}$ Seyedeh Zohreh Mirahmadi-Zareh, ${ }^{2}$ Mohammad Hossein Nasr Esfahani, ${ }^{2}$ Cornelus F. van Nostrum, ${ }^{1}$ Wim E. Hennink, ${ }^{1}$ Farid Dorkoosh ${ }^{2,4}$

\begin{abstract}
${ }^{1}$ Department of Pharmaceutics, Utrecht Institute for Pharmaceutical Sciences (UIPS), Utrecht University, Utrecht, The Netherlands. ${ }^{2}$ Department of Molecular Biotechnology at Cell Science Research Center, Royan Institute for Biotechnology, Isfahan, Iran. ${ }^{3}$ Department of Medicinal Chemistry, Faculty of Pharmacy, Esfahan University of Medical Sciences, Isfahan, Iran. ${ }^{4}$ Department of Pharmaceutics, Faculty of Pharmacy, Tehran University of Medical Sciences, Tehran, Iran.
\end{abstract}

Received, June 30, 2014; Revised, August 22, 2014; Accepted, October 16, 2014; Published, October 19, 2014.

\begin{abstract}
Purpose. The aim of this study was to investigate the in vitro gene delivery efficiency of poly[N-(2-aminoethyl)ethylene-imine](PAEEI), a polymer with a linear Polyethyleneimine (LPEI) backbone and with aminoethyl side groups that has two protonatable nitrogen atoms per monomer unit instead of one as in LPEI (an established gene delivery polymer). Method. PAEEI $(\mathrm{Mn}=4.5 \mathrm{kDa}, \mathrm{Mw}=10 \mathrm{kDa})$ was synthesized by ring-opening polymerization of $\mathrm{N}-(2-(1$ '-aziridino)ethyl)formamide followed by hydrolysis of the amide groups. The buffering capacity of the resulting polymer was determined by acid-base titration and consequently the percentage of the protonated nitrogen atoms was calculated. Polyplexes were prepared separately in buffers with different ionic strength including Hepes buffered saline $(150 \mathrm{mM} \mathrm{NaCl})$ and Hepes buffered glucose $(5 \%$ glucose) and their zeta-potential, hydrodynamic diameter and colloidal stability were measured. Transfection activity (and toxicity in Hela cells) of the polyplexes were done in HeLa, CHO and HEK293T cells. Cell incubations with polyplexes were done both in the presence and absence (HeLa cells) of serum. Results. PAEEEI showed two times more buffering capacity than LPEI. PAEEI-based Polyplexes had about the same size and zeta-potential as those of LPEI, with a higher colloidal stability in saline buffer in continuous particle size measurement. Their transfection activity was slightly higher than 22-kDa LPEI polyplexes whereas their toxicity profiles were similar in cell lines studied. The PAEEI polyplexes showed gene expression activity both in the presence and absence of serum. Conclusion. Paying attention to the fact that LPEI molecules with smaller sizes than $22 \mathrm{kDa}$ show less transfection efficiency than LPEI 22, the effect of smaller size of PAEEI (10 kDa) on the gene delivery efficiency was compensated by its higher buffering capacity due to carrying more protonatable nitrogen per monomeric unit comparing with LPEI $(22 \mathrm{kDa})$. Having slightly higher transfection efficiency and better colloidal stability than PEI-based systems, PAEEI is an attractive candidate for future in vivo gene delivery studies.
\end{abstract}

This article is open to POST-PUBLICATION REVIEW. Registered readers (see "For Readers") may comment by clicking on ABSTRACT on the issue's contents page.

\section{INTRODUCTION}

Gene delivery is defined as the process of the introduction of a foreign gene into living cells with the aim of producing a (therapeutic) protein (1-3). In addition to physical approaches for delivery of naked DNA, such as electroporation and hydrodynamic injection (4), carrier systems are frequently used for gene delivery, which can be categorized into viral and non-viral vectors (3).

The application of viral gene delivery systems, despite being very efficient, is hampered by their immunogenicity, which particularly limits their application after repeated administration (5). Furthermore, the risk of insertional mutagenesis and limitations associated with large-scale production of viral vectors are other drawbacks of this delivery

Corresponding Author: F. Dorkoosh, ${ }^{1}$ Department of Molecular Biotechnology at Cell Science Research Center, Royan Institute for Biotechnology, ACECR, 8165131387 Isfahan, Iran; ${ }^{2}$ Department of Pharmaceutics, Faculty of Pharmacy, Tehran University of Medical Sciences, Tehran, Iran. 
strategy. Therefore, non-viral delivery systems have gained more attention in recent years (5). Cationic polymers (6-11), inorganic nanoparticles (12-13), lipid nanoparticles (14), liposomes (15) and peptides (16-17) are vectors that at the present are under investigation for non-viral gene delivery.

Among cationic polymers, Polyethyleneimine (PEI) has gained a distinctive position for gene delivery purposes. Following the first introduction of PEI with molecular weights of 50 and $800 \mathrm{kDa}$ (18), this polymer became one of the most widely studied nucleic acid delivery reagents. In follow up studies, PEI of various sizes and architectures (linear versus branched) have been studied as transfection agents (19-23). Further, PEI has been conjugated with hydrophilic polymers such as polyethylene glycol (PEG) to reduce toxicity and increase its circulation half-life (24-27), as well as with targeting ligands to render them cell specific (28-30). Also, PEI-based polyplexes have been used in vivo for gene transfer studies (18-19, 31-33).

The high transfection activity of PEI based polyplexes is explained by their very high cationic charge density (18). Importantly, PEI has a high capacity for buffering protons in endosomes, a phenomenon called "the proton sponge effect" (18, 34) which likely contributes to the intrinsic endosomal escape properties of $\mathrm{PEI} / \mathrm{pDNA}$ polyplexes. Behr mentioned that one third of the nitrogen atoms of PEI become protonated when the $\mathrm{pH}$ drops from $\sim 7$ to $\sim 5$ and he argued that this contributes to the swelling and disruption of endosomes loaded with PEI-polyplexes (34).

The relationship between the proton absorbing capacity and transfection efficiency of PEI-based polyplexes has been previously investigated. To mention, Akinc et al. assessed the efficiency of gene delivery of permethyl-PEI and perethyl-PEI as $N$-quaternized variants of PEI (35). They found that, since the quaternized amines in this PEI cannot absorb protons, the transfection activity of these polyplexes were substantially lower than those of PEI polyplexes. In another study, Thomas et al. fully deacylated a commercial variant of linear PEI precursor in which some of $\mathrm{N}$ atoms in the backbone were attached to a propionyl group to obtain linear PEI (19). This modification that increased the amount of protonatable nitrogen atoms (secondary amine) in the backbone of the molecule, enhanced the buffering capacity of the polymer and showed significant improvement of the gene delivery ability of this cationic polymer (19).
Taking notice to the phenomenon of increasing the transfection activity of polyplexes by means of increasing the amount of protonatable nitrogens in the polymeric carrier, in the present study we investigated the transfection properties of polyplexes based on a previously reported PEI-like structure, namely comb-like PEI (poly[N-(2aminoethyl)ethyleneimine], PAEEI) with aminoethyl side groups. This polymer is synthesized by ring opening polymerization of $\mathrm{N}$ (2-(1'-aziridino)ethyl)formamide to yield poly[N(2-formamidoethyl)ethyleneimine] (PFEEI), that upon hydrolysis of the formamide groups results in PAEEI (36). In this polymer, the $\mathrm{N}$ atoms present in

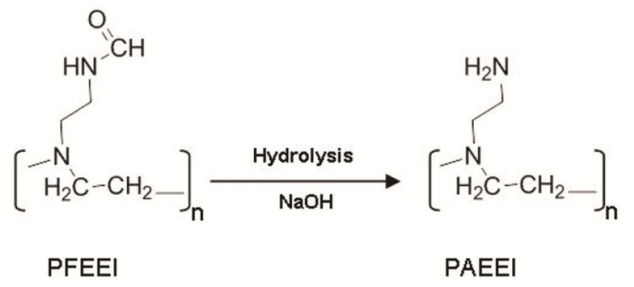

Figure 1. Hydrolysis of PFEEI to yield PAEEI. Reaction conditions: PFEEI $/ \mathrm{H}_{2} \mathrm{O}, \mathrm{NaOH}, 95^{\circ} \mathrm{C}, 5 \mathrm{~h}$.

the backbone are tertiary amines which are attached to primary ethyleneamine groups. Whereas the titration curve of linear PEI showed only one inflection point at a $\mathrm{pH}$ of around 7 due to presence of the protonatable secondary amines (37), in the paper of Koper et al., it was shown that the comblike PEI showed two protonation steps; the first one is due to protonation of the primary amines in the branches and the second one is the result of protonation of the tertiary $\mathrm{N}$ atoms in the backbone

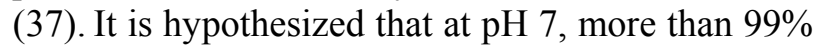
of primary amines of the comb-like PEI will be protonated giving this polymer DNA binding properties, while the tertiary amines will basically not be protonated and hence have potential of protonation in the endosome. For this reason comblike PEI could have a better ability than linear PEI to buffer protons in the endosome upon acidification. Therefore in this study, we investigated the suitability of PAEEI as polymeric transfectant.

\section{MATERIAL AND METHODS}

\section{Materials}

Aziridine was purchased from ABCR Gmbh (Baden-Württemberg, Karlsruhe, Germany). Sodium acetate, acetic acid and triethylamine were 
obtained from Merck (Darmstadt, Hesse, Germany). Dialysis membrane with Mw cut off 100-500 Da was bought from Spectrum laboratories Inc. (Fort Lauderdal, Florida). PEG standards with peak molecular weights ranging from 106 to $723500 \mathrm{Da}$ were obtained from Polymer Laboratories (Church Stretton, Shropshire, UK). All other chemicals were purchased from Sigma-Aldrich at the highest available purity. The pCMV-LacZ plasmid was purchased from the Plasmid Factory (Bielefeld, Ostwestfalen-Lippe, Germany). pCMV-LacZ is an expression plasmid, encoding for $\beta$-galactosidase under the transcriptional control of the human cytomegalovirus (CMV) promoter. Linear PEI 22 $\mathrm{kDa}$ (Exgen 500, $5.47 \mathrm{mM}$ in nitrogen residues) and desoxyribonuclease I (DNase I, $1 \mathrm{U} / \mu \mathrm{L}$ ) were purchased from Fermentas (St. Leon-Rot, BadenWürttemberg, Germany). Linear PEI $22 \mathrm{kDa}$ (in vivo-jetPEI, $150 \mathrm{mM}$ in nitrogen residues) was purchased from Polyplus-transfection SA (IllkirchGraffenstaden, Alsace, France). The Dulbecco's Modified of Eagle's Medium, with $3.7 \mathrm{~g} / \mathrm{L}$ sodium bicarbonate, $1 \mathrm{~g} / \mathrm{L}$ glucose, l-glutamine (DMEM low glucose), antibiotics/antimycotics (penicillin, streptomycin sulfate, amphotericin B), $200 \mathrm{mM}$ L-glutamine solution, fetal bovine serum (FBS) and phosphate buffered saline (PBS) were obtained from PAA Laboratories $\mathrm{GmbH}$ (Pasching, Upper Austria, Austria). Dulbecco's Modified Eagle's Medium, with $3.7 \mathrm{~g} / \mathrm{L}$ sodium bicarbonate, $4.5 \mathrm{~g} / \mathrm{L}$ glucose, l-glutamine (DMEM) was purchased from Gibco (Carlsbad, California). Dulbecco's Modified Eagle's Medium/Nutrient Mixture F-12 Ham, with $15 \mathrm{mM}$ HEPES and sodium bicarbonate (DMEM/F12), 2,3-Bis(2-methoxy-4-nitro-5-sulfophenyl)-2Htetrazolium-5-carboxanilide inner salt (XTT) and phenazine methosulfate (PMS) were bought from Sigma (St. Louis, Missouri).

\section{Synthesis of $\mathbf{N}$-(2-(1'-aziridino)ethyl)formamide}

The synthesis of $N-(2-(1 '$-aziridino $)$ ethyl $)$ formamide was performed according to a previously described method (36). Briefly, methylformate $(6.49 \mathrm{~g}, 108 \mathrm{mmol})$ was slowly added over $5 \mathrm{~h}$ to a mixture of aziridine ( $10 \mathrm{~g}, 232.5$ $\mathrm{mmol})$ and triethylamine $(0.29 \mathrm{~g}, 2.9 \mathrm{mmol})$ heated at $50{ }^{\circ} \mathrm{C}$. The mixture was stirred for $1 \mathrm{~h}$ and unreacted materials and other volatile products were removed by rotary evaporation for $3 \mathrm{~h}$. The structure of the synthesized monomer was confirmed by ${ }^{1} \mathrm{H}$ NMR in $\mathrm{D}_{2} \mathrm{O}$.

\section{Synthesis of PFEEI and PAEEI}

The synthesis of PAEEI (comb-like PEI) was performed according to the method described by Koper et al. (37) For the synthesis of PFEEI, sulfuric acid $98 \%(44 \mathrm{mg})$ was added to water (5 $\mathrm{mL})$ and the resulting solution was heated to $50^{\circ} \mathrm{C}$. Next, $\quad N$-(2-(1'-aziridino)ethyl)formamide $(5 \mathrm{~g}$, $43.86 \mathrm{mmol}$ ) was gradually added during $20 \mathrm{~min}$ and the mixture was stirred at $50{ }^{\circ} \mathrm{C}$ for $70 \mathrm{~h}$. Subsequently, the solution was dialyzed for 3 days at $4{ }^{\circ} \mathrm{C}$ against purified water (membrane cut off 100-500 Da). The polymer was obtained after freeze-drying and stored at $-20^{\circ} \mathrm{C}$. For the synthesis of PAEEI, $\mathrm{NaOH}(71 \mathrm{mg}, 1.8 \mathrm{mmol})$ was dissolved in distilled water $(0.68 \mathrm{~mL})$, followed by the addition of PFEEI $(200 \mathrm{mg}$ ). The solution was stirred for $5 \mathrm{~h}$ at $95^{\circ} \mathrm{C}$ and after cooling down, dialyzed for 3 days at $4{ }^{\circ} \mathrm{C}$ against distilled water (membrane cut off 100-500 Da). The polymer was obtained after freeze-drying and stored at $-20^{\circ} \mathrm{C}$.

\section{Polymer Characterization}

The synthesized polymers were characterized by proton nuclear magnetic resonance (NMR) $\left(\mathrm{D}_{2} \mathrm{O}\right)$ recorded on a Varian Innova spectrometer (300 $\mathrm{MHz}$ ). Molecular weights were determined by gel permeation chromatography (GPC) relative to PEG standards using a Waters ${ }^{\mathrm{TM}}$ HPLC system (Waters Corp., USA) equipped with a refractive index detector. Plotting a calibration curve related to 16 PEG standards with different peak molecular weights ranging from 106 to $723500 \mathrm{Da}$, Empower software, version 2.0 (Waters Corp., USA) calculated $M_{w}$ and $M_{n}$ of the samples based on the retention time of each molecule. The GPC measurements were performed with two columns, Shodex OHpak SB-804M and a precolumn Shodex SB-G (Showa Denko, Japan) in series. The columns were thermostated at $30^{\circ} \mathrm{C}$ and the eluent was sodium acetate buffer $(0.3 \mathrm{M}, \mathrm{pH} 4.4)$ with a flow rate of $1 \mathrm{~mL} / \mathrm{min}$ (38). $M_{n}$ and $M_{w}$ of in vivo-jetPEI (linear PEI $22 \mathrm{kDa}$ ) were measured as control.

\section{Buffer Capacity}

The buffer capacity of PFEEI and PAEEI was determined by an acid-base titration method (39, 40).In short, the polymers were dissolved at a concentration of $50 \mathrm{mM}$ of theoretical protonatable nitrogen atoms in $150 \mathrm{mM} \mathrm{NaCl}$. The $\mathrm{pH}$ of the obtained solutions $(10 \mathrm{~mL})$ was adjusted to 2.0 using $1.0 \mathrm{M} \mathrm{HCl}$ to protonate almost all nitrogen atoms (41). Next, the solutions were titrated with 
$0.1 \mathrm{M} \mathrm{NaOH}$ to $\mathrm{pH} 10.5$. The buffer capacity is defined as the percentage of the nitrogens that become deprotonated from $\mathrm{pH} 5.1$ to $\mathrm{pH} 7.4$ and was calculated using the following equation (39):

\section{Buffer capacity $=\left\{\left[\mathrm{C}_{\mathrm{NaOH}} \cdot\left(\Delta \mathrm{V}_{\mathrm{pH}}\right.\right.\right.$.4- 5.1(polymer solution) - $\left.\left.\left.\Delta \mathrm{V}_{\mathrm{pH} 7.4-5.1(\mathrm{NaCl} \text { solution })}\right)\right] / \mathrm{n}_{\text {protonatable nitrogens }}\right\} \times 100 \%$} The charge density of the polymers (proportional to the percentage of protonated amines) at a certain $\mathrm{pH}$ was calculated as follows:

Percentage of protonated amines at a given $\mathrm{pH}$

$$
\begin{aligned}
& =\left\{1-\left\{\left[\mathrm { C } _ { \mathrm { NaOH } } \cdot \left(\mathrm{V}_{\mathrm{pH} \text { (polymer solution) }}-\mathrm{V}_{\mathrm{pH} \text { ( } \mathrm{NaCl} \text { solution) })] /}\right.\right.\right.\right. \\
& \left.\left.\mathrm{n}_{\text {protonatable nitrogens }}\right\}\right\} \times 100 \%
\end{aligned}
$$

In these equations, $\mathrm{C}_{\mathrm{NaOH}}$ is molarity of $\mathrm{NaOH}$ solution, $\Delta \mathrm{V}_{\mathrm{pH} 7.4-5.1}$ is difference between added volumes of $\mathrm{NaOH}$ solution in $\mathrm{pH}$ of 7.4 and $\mathrm{pH}$ of 5.1 in the related solutions (equation 1), $\mathrm{V}_{\mathrm{pH}}$ is added volume of $\mathrm{NaOH}$ solution at the given $\mathrm{pH}$ (equation 2) and $n_{\text {protonatable nitrogens }}$ is the moles of protonatable nitrogen atoms in both equations.

Also, LPEI was synthesized according to the method described by Yang et al. (42) to be available for titration as a control.

\section{Preparation of Polyplexes}

Polyplexes were obtained according to the standard protocols described by van Gaal et al. (43). Polyplexes dispersions were prepared at nitrogento-phosphate (N/P) ratios ranging from 5 to 160 for PFEEI and from 3 to 40 for PAEEI and linear PEI $22 \mathrm{kDa}$ respectively, in either Hepes buffered glucose (HBG; $20 \mathrm{mM}$ HEPES, $5 \%$ (w/w) glucose, $\mathrm{pH}$ 7.4) or Hepes buffered saline (HBS; $20 \mathrm{mM}$ HEPES, $150 \mathrm{mM} \mathrm{NaCl}$, pH 7.4). Twenty $\mu \mathrm{L}$ of polymer solution with an amount of polymer to yield the desired N/P was prepared in HBG or HBS buffer. Next, the polymer solution was added to 5 $\mu \mathrm{L}$ of plasmid solution with concentrations of 50 or $100 \mu \mathrm{g} / \mathrm{mL}$ in the same buffer and was mixed by vortexing for $5 \mathrm{sec}$, followed by incubation at room temperature for $30 \mathrm{~min}$.

\section{Gel Retardation Assay}

Polyplexes were obtained as described above with $0.5 \mu \mathrm{g}$ DNA (from a $250 \mu \mathrm{g} / \mathrm{mL}$ stock solution of DNA) in HBS buffer and at N/P ratios of $0.5,1,2$, 5, 10 and 20 for PFEEI and PAEEI, and 6 and 10 for linear PEI $22 \mathrm{kDa}$. After $30 \mathrm{~min}$ incubation at room temperature, samples of the dispersion $(25$ $\mu \mathrm{L})$ were loaded into the gel $(0.8 \% \mathrm{w} / \mathrm{v}$ agarose containing $0.5 \% \mathrm{w} / \mathrm{v}$ ethidium bromide in Trisacetate ( $\mathrm{pH}$ 8.0) as running buffer and electrophoresis was performed for $30 \mathrm{~min}$ at $100 \mathrm{~V}$. In another experiment, after adding the polymer solution to the DNA solution ( $\mathrm{N} / \mathrm{P}$ ratios as mentioned above), FBS was added to the samples to a final concentration of $10 \% \mathrm{v} / \mathrm{v}$ FBS and after vortexing for $5 \mathrm{sec}$, the polyplexes were incubated at $37^{\circ} \mathrm{C}$ for $1 \mathrm{~h}$ before running the gel as described above.

For investigation of DNA protection against deoxyribonuclease degradation, the following experiment was done. Polyplexes, obtained as mentioned above at $\mathrm{N} / \mathrm{P}$ ratios ranging from 0.5 to 20 , were incubated for $30 \mathrm{~min}$ at room temperature. Then, $2.5 \mu \mathrm{L}$ of a DNAse I solution in water (2 units $/ \mathrm{mL}$ ) was added and the samples were incubated at $37^{\circ} \mathrm{C}$ for $5 \mathrm{~h}$. Thereafter, the enzyme was inactivated by adding $1.1 \mu$ EDTA $(500 \mathrm{mM}$ in water, $\mathrm{pH}$ adjusted to 8.4). Subsequently, $1 \mu \mathrm{L}$ heparin solution $(10 \mathrm{mg} / \mathrm{mL}$ in water) was added and the samples were incubated for $1 \mathrm{~h}$ at $37^{\circ} \mathrm{C}$ in order to destabilize the polyplexes. After that, the samples were analyzed by gel electrophoresis as described above.

\section{Zeta-Potential and Size Measurements of Polyplexes}

The zeta-potential of the polyplexes prepared in HBG buffer at N/P ratios ranging from 0.5 to 20 was measured using a Malvern Zetasizer Nano-Z (Malvern Instruments, Malvern, UK) with universal ZEN 1002 'dip' cells and DTS (Nano) software (version 6.01). The Helmholtz-Smoluchowski equation (44) was used for converting the measured electrophoretic mobilities into zeta-potentials. The system was calibrated with DTS latex beads (Zeta Potential Transfer Standard, Malvern Instruments, Malvern, UK). The experiments were done in triplicate.

Particle size of the polyplexes was measured in HBS (viscosity $0.89 \mathrm{cP}$, refractive index 1.333) or HBG (viscosity $1.15 \mathrm{cP}$, refractive index 1.340) after $30 \mathrm{~min}$ of incubation at room temperature with dynamic light scattering (DLS) using an ALV CGS-3 system (Malvern Instruments, Malvern, UK) equipped with a JDS Uniphase $22 \mathrm{~mW}$ He-Ne laser (JDS Uniphase Corp., USA) operating at $632.8 \mathrm{~nm}$, an optical fiber-based detector, a digital LV/LSE-5003 correlator (ALV-Laser Vertriebsgesellschaft m-b.H., Germany) and a temperature controller (Julabo water bath, JULABO 
$\mathrm{GmbH}$, Germany) set at $25^{\circ} \mathrm{C}$. Time correlation functions were analyzed to obtain the hydrodynamic diameter of the particles $\left(Z_{\mathrm{h}}\right)$ and the particle size distribution (polydispersity index, PDI) using the ALV-60X0 software V.3.X (Malvern, UK). Scattering was measured in an optical quality $4 \mathrm{~mL}$ borosilicate cell at a $90^{\circ}$ angle. The system was calibrated with $200 \mathrm{~nm}$ polystyrene latex standard beads (Duke Scientific, Leusden, The Netherlands). The experiments were done in triplicate.

The colloidal stability of the polyplexes was studied by DLS. Polyplexes of PFEEI and PAEEI at $\mathrm{N} / \mathrm{P}$ ratios of 3-20 and linear PEI $22 \mathrm{kDa}$ at N/P ratios of 6 and 10 were prepared in HBG buffer and were incubated at room temperature for $30 \mathrm{~min}$. Then, sufficient amount of concentrated HBS buffer (40 mM HEPES, $300 \mathrm{mM} \mathrm{NaCl}, \mathrm{pH}$ 7.4) was added to each sample (to make final concentration of 150 $\mathrm{mM} \mathrm{NaCl}$ ) and mixed by vortexing for $5 \mathrm{sec}$. Next, the samples were measured with DLS for $16 \mathrm{~h}$ at $37^{\circ} \mathrm{C}$.

\section{Cell Cultures}

HeLa cells were grown in Dulbecco's Modified Eagle Medium (DMEM) with $1 \mathrm{~g} / \mathrm{L}$ glucose. HEK293T cells were grown in DMEM with $4.5 \mathrm{~g} / \mathrm{L}$ glucose and $\mathrm{CHO}$ cells were grown in DMEM/F12. The media contained $10 \%$ FBS. Cells were maintained at $37{ }^{\circ} \mathrm{C}$ in a $5 \% \mathrm{CO}_{2}$ humidified air atmosphere.

\section{Transfection Studies}

HeLa, HEK293T, and CHO cells were transfected with polyplexes with pCMV-LacZ expressing $\beta$ galactosidase as reporter gene added to the cells in the medium containing $10 \%$ serum. In detail, 8000 cells were seeded per well into 96-well tissue culture plates $24 \mathrm{~h}$ prior to transfection. Subsequently, the culture medium was refreshed with $100 \mu \mathrm{L}$ DMEM supplemented with $10 \%$ FBS. Next, $25 \mu \mathrm{L}$ of the polyplex dispersion (corresponding with 0.25 or $0.5 \mu \mathrm{g} \mathrm{DNA} /$ well) was added per well and after $4 \mathrm{~h}$ the medium was refreshed with DMEM supplemented with $10 \%$ FBS. For transfection of HeLa cells in serum-free medium, the cells were washed with PBS buffer and refreshed with DMEM prior to addition of the polyplex dispersion. Cells were incubated for $48 \mathrm{~h}$ at $37{ }^{\circ} \mathrm{C}$ in a $5 \% \mathrm{CO}_{2}$ humidified air atmosphere and evaluated for expression of $\beta$-galactosidase.

\section{$\beta$-Galactosidase Assay}

The extent of $\beta$-galactosidase expression by the transfected cells was determined by conversion of ortho-nitrophenyl- $\beta$ - D-galactopyranoside (ONPG), a chromogenic colorless substrate, into its product, ortho-nitrophenol (ONP), which gives yellow color after enzymatic action. In short, $48 \mathrm{~h}$ after transfection, the cells were washed with $100 \mu \mathrm{L}$ ice-cold PBS and lysed with $20 \mu \mathrm{L}$ lysis buffer (50 $\mathrm{mM}$ Tris-HCl buffer ( $\mathrm{pH} 8.0), 150 \mathrm{mM} \mathrm{NaCl}$ and $1 \%$ Triton $\mathrm{X}-100$ ) during $20 \mathrm{~min}$ at $4{ }^{\circ} \mathrm{C}$. Then, 180 $\mu \mathrm{L}$ ONPG-staining solution (18.5 mL PBS, $200 \mu \mathrm{l}$ $0.1 \mathrm{M} \mathrm{MgCl}_{2}$-solution and $1.35 \mathrm{ml} 10 \mathrm{mg} / \mathrm{mL}$ ONPG-solution in PBS) was added and the $\beta$-galactosidase activity was determined by measuring the absorbance of the sample at $415 \mathrm{~nm}$ relative to the absorbance at $655 \mathrm{~nm}$ as reference wave length (to correct background of cell debris) after 30 min incubation at $37^{\circ} \mathrm{C} .{ }^{42}$ The experiments were done in triplicate.

\section{Cell Proliferation/Viability Assay (XTT)}

The cell viability was determined using a XTT colorimetric assay that is based on cleavage of a tetrazolium reagent to form an orange formazan dye, which is indicative for cell metabolic activity. ${ }^{42}$ In short, $48 \mathrm{~h}$ after transfection, $50 \mu \mathrm{XTT}$-solution (0.025 mM PMS and $1.5 \mathrm{mM}$ XTT in plain RPMI 1640) was added per well after refreshment of the medium with $100 \mu \mathrm{L}$ DMEM supplemented with 10 $\%$ FBS per well and incubated for $1 \mathrm{~h}$ at $37^{\circ} \mathrm{C}$ in a $\mathrm{CO}_{2}$-incubator. Absorbance was measured at 490 $\mathrm{nm}$ with a reference wavelength of $655 \mathrm{~nm}$. The experiments were done in triplicate.

\section{RESULTS AND DISCUSSION}

Synthesis and Characterization of $\mathrm{N}-(2-(1)-$ aziridino)ethyl)formamide, Poly[N-(2formamidoethyl)ethyleneimine] (PFEEI) and Poly[N-(2-aminoethyl)ethylene-imine](PAEEI) $N$-(2-(1'-aziridino)ethyl)formamide was obtained by reaction of aziridine and methylformate (yield: $61 \%$ ). The driving force for this reaction is the formation of the intermediate $N$-formyl aziridine, which is prone to nucleophilic ring opening by another aziridine molecule. Based on the wellknown mechanism of nucleophilic addition (41), a suggested mechanism for this reaction is illustrated in supporting information (Figure 1S). The structure 
of the synthesized monomer was confirmed by ${ }^{1} \mathrm{H}$ NMR (Figure 2S in supporting information).

PFEEI was synthesized by ring opening polymerization of $N$-(2-(1'-aziridino) ethyl) formamide in an aqueous solution at $50{ }^{\circ} \mathrm{C}$ using sulfuric acid as catalyst. The ${ }^{1} \mathrm{H}$ NMR spectrum of the product showed that the monomer conversion was almost complete after $70 \mathrm{~h}$ (Figure. 2S). The formamide side groups of PFEEI were quantitatively removed by hydrolysis that was catalyzed by $\mathrm{NaOH}$ at $95^{\circ} \mathrm{C}$ in order to obtain PAEEI (Figure. 1) in a yield of $100 \%$. ${ }^{1} \mathrm{H}$ NMR confirmed the structure of PFEEI and PAEEI. The assigned positions of the different peaks of ${ }^{1} \mathrm{H}$ NMR spectra of the polymers are explained and depicted in supporting information (Figure 2S).

Different experiments were performed to obtain monomer with a lower oligomer content. We observed that the oligomer content had impact on the kinetics of the polymerization reactions and the molecular weight of the final polymer $\left(M_{w}\right.$ ranged from 6.2 to $10.4 \mathrm{kDa}$, data not shown). In this study we focused on the molecular weight of $10 \mathrm{kDa}$ because smaller sizes had not shown remarkable transfection activity in our preliminary screening assessments.
GPC analysis using PEG standards showed that the $M_{w}$ of PFEEI and PAEEI were $10.2 \mathrm{kDa}$ and $10.1 \mathrm{kDa}$, respectively, and the $M_{n}$ of these two polymers were 3.8 and $4.5 \mathrm{kDa}$, respectively. This means that the hydrolysis of amide groups was not associated with chain scission. Also, the $M_{n}$ and $M_{w}$ of in vivo-jetPEI (linear PEI $22 \mathrm{kDa}$ ) were measured to be 21.9 and $37.8 \mathrm{kDa}$ (RSD: $3.9 \%$ and $0.9 \%, n=3$ ) respectively, to show that measurement of molecular size of PEI based polymers, especially linear structures, using GPC with PEG standards and water-based eluents, is reliable.

\section{Buffering Capacity of PFEEI and PAEEI}

Figure 2 depicts the titration curves and their first derivative $(\Delta \mathrm{pH} / \Delta$ volume versus volume $)$ of PFEEI and PAEEI. Using equation 1 and Figure 2A, the buffering capacity was determined to be $25 \%, 14 \%$ and $7 \%$ for PFEEI , PAEEI and LPEI respectively, demonstrating that PAEEI has higher potential of proton absorption than LPEI (approximately 2 two times), specifically in the physiologic condition.

Figure 2B depicts that the inflection point(s) of the polymers are at $\mathrm{pH}$ of 4.2 for PFEEI and 4.4 and 6.9 for PAEEI.

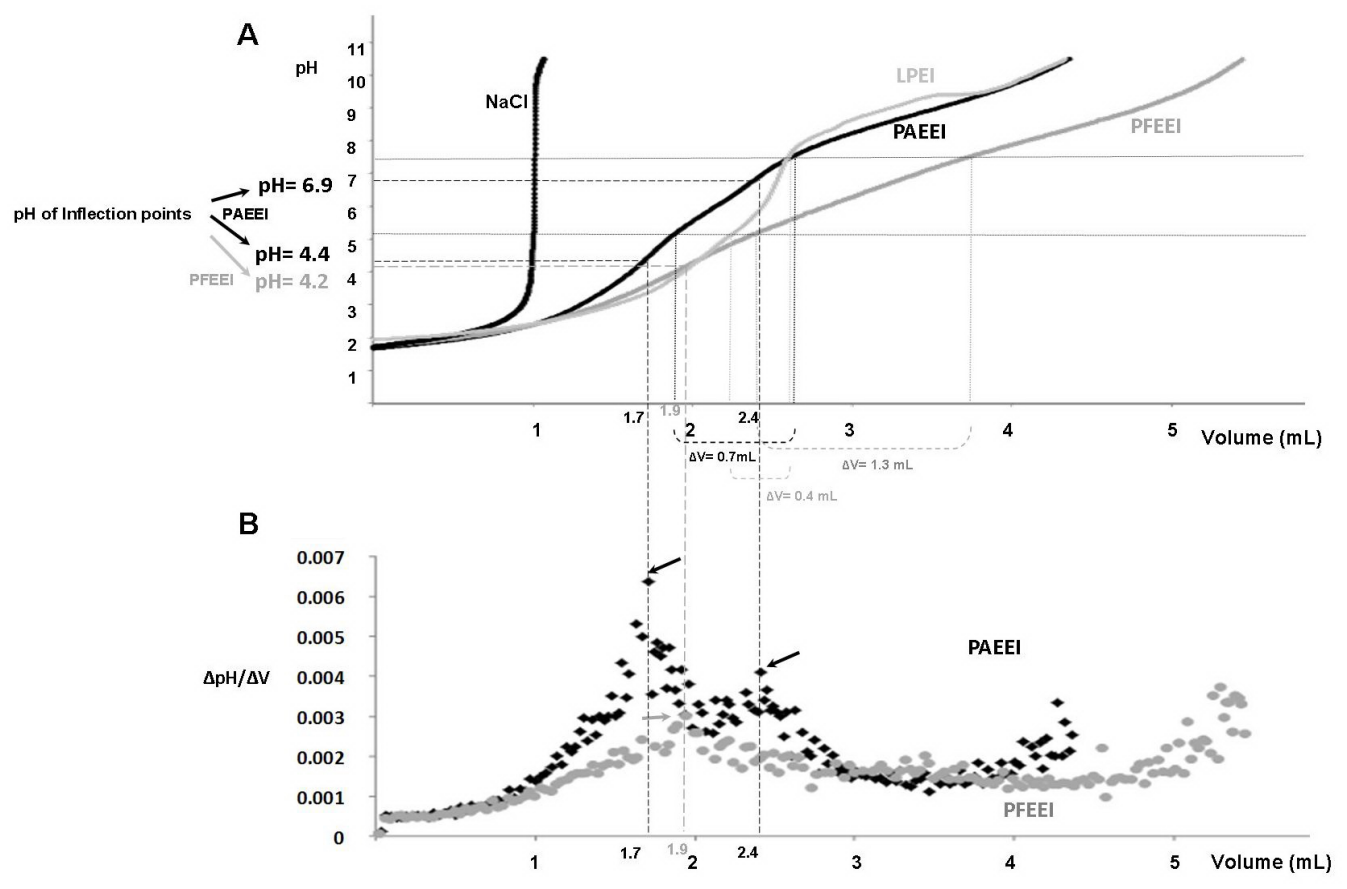

Figure 2. Titration curves of PFEEI, PAEEI and LPEI with $0.1 \mathrm{M} \mathrm{NaOH}(\mathrm{A})$ and plot of $\Delta \mathrm{pH} / \Delta \mathrm{V}$ versus volume (B). The arrows in part $\mathrm{B}$ show the inflection points. The $\mathrm{pH}$ values that are relevant to each inflection point are illustrated in part $\mathrm{A}$. 
PFEEI showed one inflection point as it has one type of protonatable nitrogen that is the tertiary amine in the backbone of the polymer. PAEEI, however, showed two inflection points because it has primary amines in the branches in addition to the tertiary amines in the backbone that is in line with what has been reported previously by Koper et al. ${ }^{37}$

Using the data of Figure 4, it was calculated (equation 2 ) that $69 \%$ and $48 \%$ of the protonatable nitrogen atoms (16 and $4 \mathrm{mmol} \mathrm{N}$ atoms per gram of polymer) in PAEEI and PFEEI, respectively, were protonated at $\mathrm{pH} \mathrm{7.4,} \mathrm{which} \mathrm{is} \mathrm{explained} \mathrm{by}$ the presence of two protonatable nitrogen atoms (primary and tertiary amines) in the monomer units of PAEEI instead of one protonable nitrogen atom in that of PFEEI (only tertiary amine). Obviously, the presence of more protonatable nitrogen atoms in the molecule results in increase of the proton absorption capacity.

\section{Gel Retardation Assay}

Figure 3 shows the gel electrophoresis analysis of polyplexes based on PAEEI and PFEEI (prepared at
$\mathrm{N} / \mathrm{P}$ ratios of 0.5 to 20$)$ as well as that of linear PEI $22 \mathrm{kDa}(\mathrm{N} / \mathrm{P}$ ratio of 6 and 10). Results show that both PFEEI and PAEEI, as well as linear PEI, completely retained DNA at N/P ratios of 5 and higher, both in the absence and presence of serum (Figure 3A and 3B, respectively). Figure 3C shows that the polyplexes prepared at N/P ratios $>5$ completely protected DNA against degradation induced by DNAase I since the DNAse I exposed polyplexes released the intact DNA upon incubation with heparin.

\section{Zeta-potential and Size Measurements}

Figure 4 shows that at N/P ratios of 3 and 6 or higher, the zeta-potentials of PFEEI and PAEEI polyplexes were positive, respectively, whereas at lower ratios their zeta-potentials were negative. At $\mathrm{N} / \mathrm{P}$ ratios of 6 to 20 , the zeta-potential of the polyplexes based on PAEEI (20-22 $\mathrm{mV})$ was higher than that of the PFEEI polyplexes (15-16 $\mathrm{mV}$ ). These results can be explained by the higher charge density of PAEEI at $\mathrm{pH} 7.4$ as compared with its precursor, PFEEI.

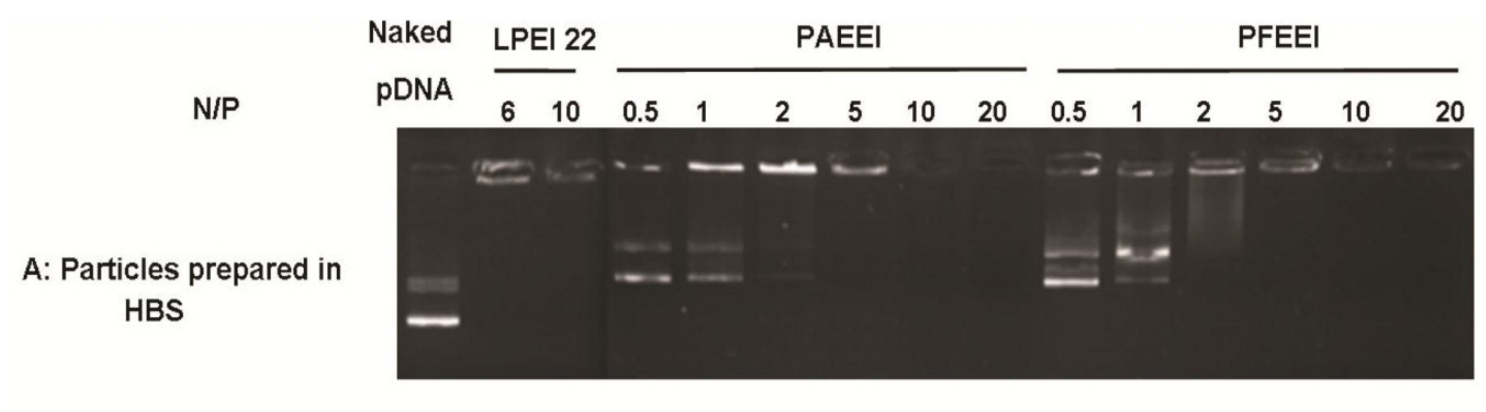

B: $10 \%$ serum-treated

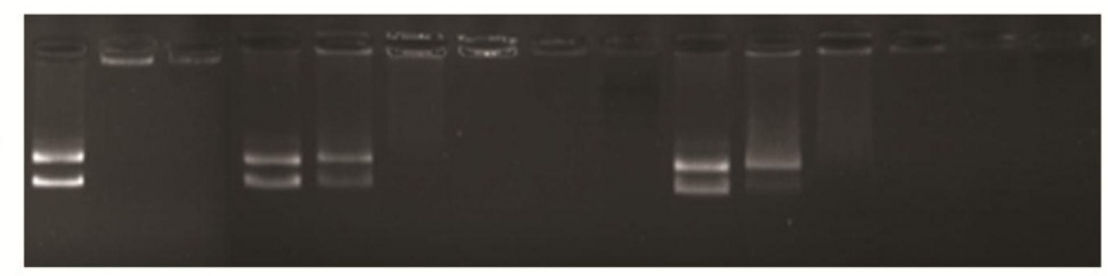

particles

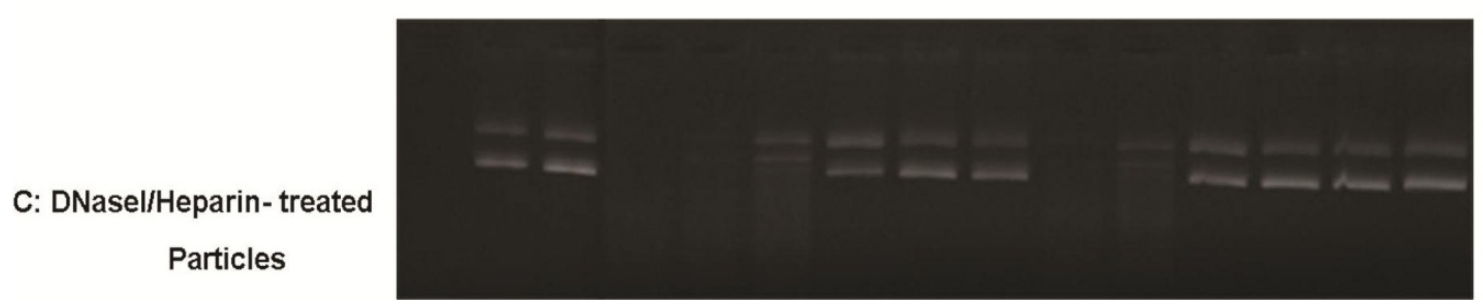

Figure 3. A) Gel retardation assay of polyplexes (different N/P ratios) based on PFEEI and PAEEI made in HBS buffer. B) Incubation of the particles in FBS (10\% FBS in final volume). C) Protection of DNA by the polymers against degradation catalyzed by DNase I. After preparation, polyplexes were incubated with DNAse I for 5 h. After inactivation of DNase I, the polyplexes were treated with heparin to release pDNA. Linear PEI $22 \mathrm{kDa}$ (LPEI 22) polyplexes prepared at $\mathrm{N} / \mathrm{P}$ ratios of 6 and 10 were used as control. 


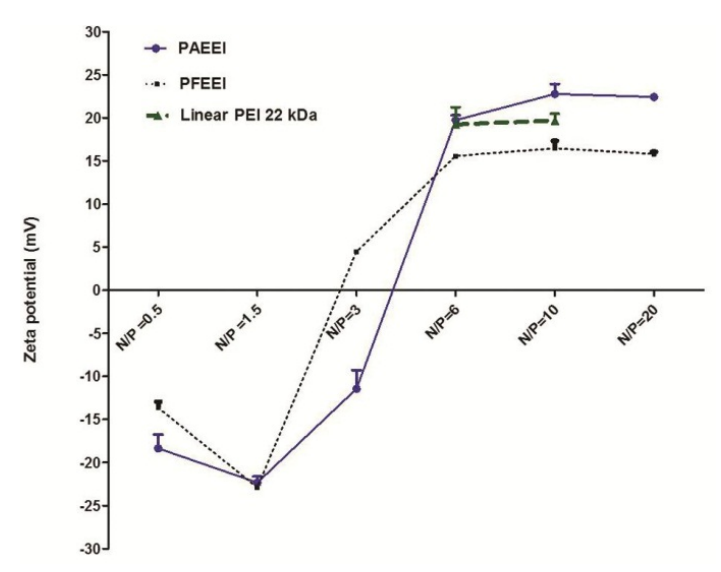

Figure 4. Zeta potential of polyplexes based on PFEEI and PAEEI prepared at different N/P ratios. Linear PEI $22 \mathrm{kDa}$ polyplexes prepared at N/P ratios of 6 and 10 were used as control. Data are shown as mean $\pm \mathrm{SD}(\mathrm{n}=3)$.

Formulations of both polymers with DNA at $\mathrm{N} / \mathrm{P}$ ratio of 0.5 prepared in both $\mathrm{HBG}$ and HBS had too low scattering intensity for reliable measurement pointing to an insufficient DNA binding capacity of the polymers under these conditions. Figure $5 \mathrm{~A}$ shows the results of DLS measurements of the particles prepared in HBG buffer at $\mathrm{N} / \mathrm{P} \geq 1.5$. This Figure depicts typical bellshaped curves that are similar to what has been observed for PEI and other cationic polymers (40, 45).

At $\mathrm{N} / \mathrm{P}$ ratio of 1.5 , polyplexes with a hydrodynamic diameter of $98 \pm 6$ and $65 \pm 18 \mathrm{~nm}$ for PFEEI and PAEEI, respectively, were observed. At $\mathrm{N} / \mathrm{P}$ ratio of 3 , aggregated particles with sizes around 600-800 nm were detected, which are likely formed to their low zeta-potential. At N/P ratio of 6 and higher, small positively charged particles were formed. PAEEI produced smaller particles (74-99 $\mathrm{nm})$ compared to PFEEI $(\sim 120 \mathrm{~nm})$, which is likely due to its higher charge density at $\mathrm{pH} 7.4$ resulting in stronger DNA binding and condensation. DLS measurement showed that the size of linear PEI 22 $\mathrm{kDa}$ based polyplexes was smaller than PAEEI and PFEEI based polyplexes which is explained by higher $M_{w}$ of linear PEI $22 \mathrm{kDa}$ compared with PAEEI and PFEEI $\left(M_{w}=10 \mathrm{kDa}\right)$. The impact of polymer $M_{w}$ on hydrodynamic diameter of the PEI/DNA particles has been reported previously (46).

Figure 5B shows the results of DLS measurements of the particles prepared in HBS buffer. At an N/P ratio of 3, large particles (size between 1000 and $2000 \mathrm{~nm}$ ) were formed. However, at increasing N/P ratios, a reduction in size was observed (for example: $335 \pm 63$ and $319 \pm 9$ $\mathrm{nm}$ at an N/P ratio of 20 for PFEEI and PAEEI, respectively).

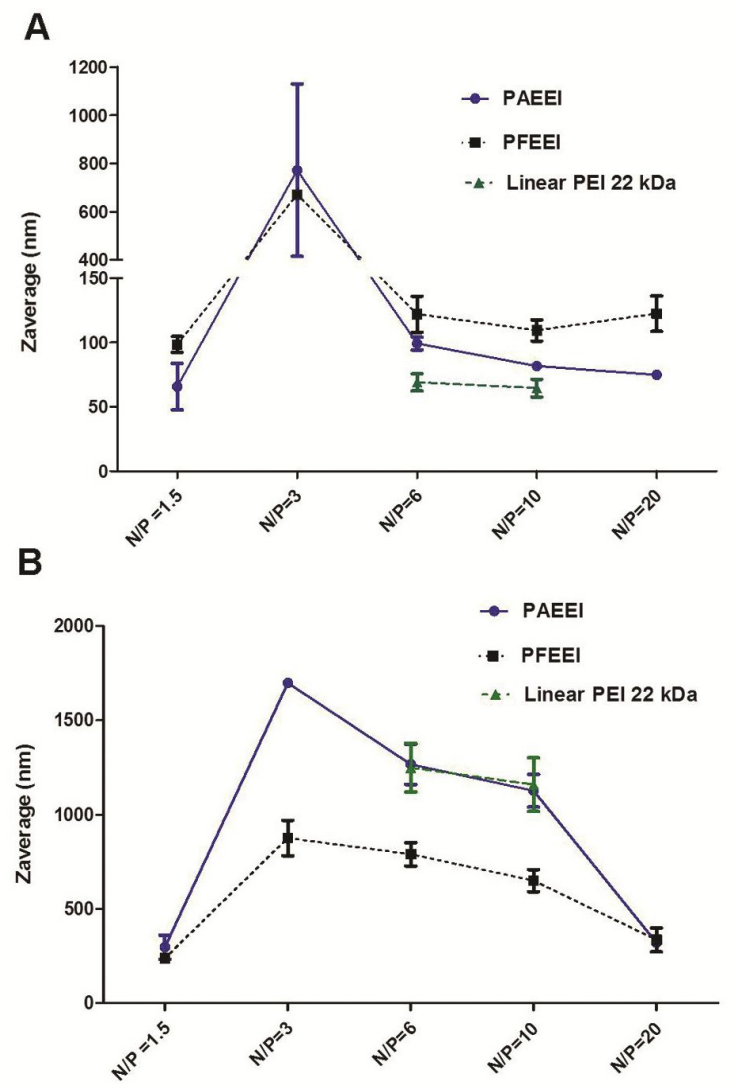

Figure 5. DLS measurements of polyplexes based on PFEEI and PAEEI made in HBG (A) and HBS (B) buffer at different $\mathrm{N} / \mathrm{P}$ ratios as determined by DLS. Linear PEI $22 \mathrm{kDa}$ polyplexes prepared at $\mathrm{N} / \mathrm{P}$ ratios of 6 and 10 were used as control. Data are shown as mean $\pm \mathrm{SD}(\mathrm{n}=3)$.

Figure 5 shows that, at the same N/P ratio, the diameters of the particles made in HBS buffer were greater than those of the particles prepared in HBG buffer. Most likely, at higher ionic strength, the electrostatic repulsion between the polyplex particles decreases which results in some aggregation and thus in bigger particles (43).

The results of Figure 4 and 5 were obtained for polyplexes prepared at a fixed pDNA concentration of $10 \mu \mathrm{g} / \mathrm{mL}$. Size and zeta-potential measurements of PAEEI polyplexes at higher pDNA concentration $(20 \mu \mathrm{g} / \mathrm{mL})$ prepared in both HBG and HBS at an $\mathrm{N} / \mathrm{P}$ ratio of 20 were carried out (Table 1 ). The results show that polyplexes prepared at $20 \mu \mathrm{g} / \mathrm{mL}$ pDNA had slightly higher zeta-potential than those 
prepared at $10 \mu \mathrm{g} / \mathrm{mL}$ and were also slightly bigger. It was predictable that higher DNA concentration results in more aggregation and change in surface charge. Also, the effect of DNA concentration on the condensation ability of cationic polymers has been studied before for another polymeric system, and the authors concluded that with increasing DNA concentration, the capacity of a cationic polymer for DNA condensation decreases (47).

DLS measurements were carried out to investigate the time-dependent colloidal stability of polyplexes based on PFEEI and PAEEI at N/P ratios of 3-20 and linear PEI $22 \mathrm{kDa}$ at N/P ratios of 6 and 10, after preparation in HBG and subsequently dilution in a concentrated HBS buffer to obtain a final concentration of $150 \mathrm{mM} \mathrm{NaCl}$. At an N/P ratio of 3, polyplexes of PFEEI and PAEEI showed large sizes (900 and $2000 \mathrm{~nm}$ ), indicating that aggregation occurred in a few seconds in buffer with $150 \mathrm{mM} \mathrm{NaCl}$. At N/P ratios of 6 and 10 , particle sizes of polyplexes of both polymers and also linear PEI were around $400 \mathrm{~nm}$ after adjusting the $\mathrm{NaCl}$ concentration to $150 \mathrm{mM}$ and their sizes increased in 15 minutes to $>500 \mathrm{~nm}$. After addition of the concentrated HBS buffer, the sizes of PAEEI based polyplexes (N/P ratio 20) after 45 minutes were smaller than $500 \mathrm{~nm}$, indicating that polyplexes made with the comb-like PAEEI showed the highest colloidal stability. Also, PAEEI based polyplexes with higher DNA concentration (20 $\mu \mathrm{g} / \mathrm{mL}$ DNA) showed sizes $<500 \mathrm{~nm}$ after bringing the $\mathrm{NaCl}$ concentration to $150 \mathrm{mM}$. It is concluded that in buffer with $150 \mathrm{mM} \mathrm{NaCl}$ polyplexes based on comb-like PEI at N/P ratio of 20 showed slower aggregation kinetics than polyplexes based on linear PEI $22 \mathrm{kDa}$. This higher colloidal stability can be explained by the higher zeta-potential of PAEEI based polyplexes compared with linear PEI $22 \mathrm{kDa}$ based polyplexes.

\section{Cytotoxicity and In vitro Gene Expression of Polyplexes}

The XTT assay showed that polyplexes based on PFEEI had a very good metabolic activity in HeLa cells (cell viability was around $100 \%$ up to polymer concentrations of $0.07 \mathrm{mg} / \mathrm{mL}$ in the dispersion. At this concentration, PEI based polyplexes are cytotoxic for the tested cell lines). This good cytocompatibility of PFEEI is in line with previous reports in which it is shown that the cytotoxicity of polymers with tertiary amines is lower than those carrying primary amines (48). At N/P ratio of 20 and less, the PAEEI based polyplexes showed comparable cytocompatibility as those based on linear PEI 22kDa (Figure 6A). Further, in the absence of serum, the toxicity of the polyplexes was higher than in its presence. Likely, serum proteins mask the cytotoxicity of cationic polyplexes as previously reported for other systems (43, 49-50).

Polyplexes based on PFEEI did not show detectable gene transfection, even at $\mathrm{N} / \mathrm{P}$ ratio of 160 (results not shown). It has been reported before that polyplexes only show transfection when they exhibit some cytotoxicity (51).In contrast to polyplexes based on PFEEI, PAEEI polyplexes prepared in both saline and low ionic strength buffer showed transfection in $\mathrm{HeLa}$ cells comparable with the golden standard, linear PEI 22 $\mathrm{kDa}$, both in the absence and presence of serum (Figure 6B).

It has been previously reported that the molecular weight of PEI is important for its transfection efficiency, the higher the molecular weight, the higher the transfection activity $(22,52)$; in such a way that the gene delivery efficiency of linear PEI $22 \mathrm{kDa}$ is higher than that of the smaller molecular weights of linear PEI (52) to make it as the only commercially available transfection reagent based on linear PEI. In this study, we observed that polyplexes based on PAEEI $10 \mathrm{kDa}$ showed, despite its lower molecular weight, a slightly higher transfection activity than linear PEI $22 \mathrm{kDa}$ in HeLa cells (Figure 6B). This observation can be ascribed to the fact that this polymer has two protonatable nitrogens in its monomeric unit as compared to linear PEI which has only one. This implies increased protonatable nitrogen atoms in each monomeric unit of PAEEI that results in finding 2 steps of protonation and 2 times more buffering capacity to compensates for its lower molecular weight. Further, the cytocompa-tibility of this structure in this special molecular weight was comparable with linear PEL $22 \mathrm{kDa}$ as well.

Due to the difference in the hydrodynamic diameter and colloidal stability of the polyplexes made in low and high ionic strength buffers, the gene expression and cytotoxicity assessments were performed with particles made in HBG and HBS buffers separately. It was observed that the results of PAEEI based polyplexes made in both HBG and HBS were comparable with linear PEI $22 \mathrm{kDa}$ based polyplexes made in the same condition (Figure 6). 
Table 1. Zeta-potential and size of polyplexes based on PAEEI at an N/P ratio of 20 and at two different DNA concentrations. Polyplexes were prepared in HBG and HBS buffer. Data are shown as mean \pm SD $(n=3)$. Size and zeta potential of the polyplexes were measured after $30 \mathrm{~min}$ incubation at room temperature.

DNA Concentration

\begin{tabular}{lcc}
\cline { 2 - 3 } & $10 \mu \mathrm{g} / \mathrm{mL}$ & $20 \mu \mathrm{g} / \mathrm{mL}$ \\
\hline Zeta potential (mV) & $22.4 \pm 0.3$ & $26.0 \pm 0.4$ \\
Particle size in HBG buffer $(\mathrm{nm})$ & $87 \pm 5$ & $127 \pm 1$ \\
Particle size in HBS buffer $(\mathrm{nm})$ & $320 \pm 9$ & $588 \pm 52$ \\
\hline
\end{tabular}
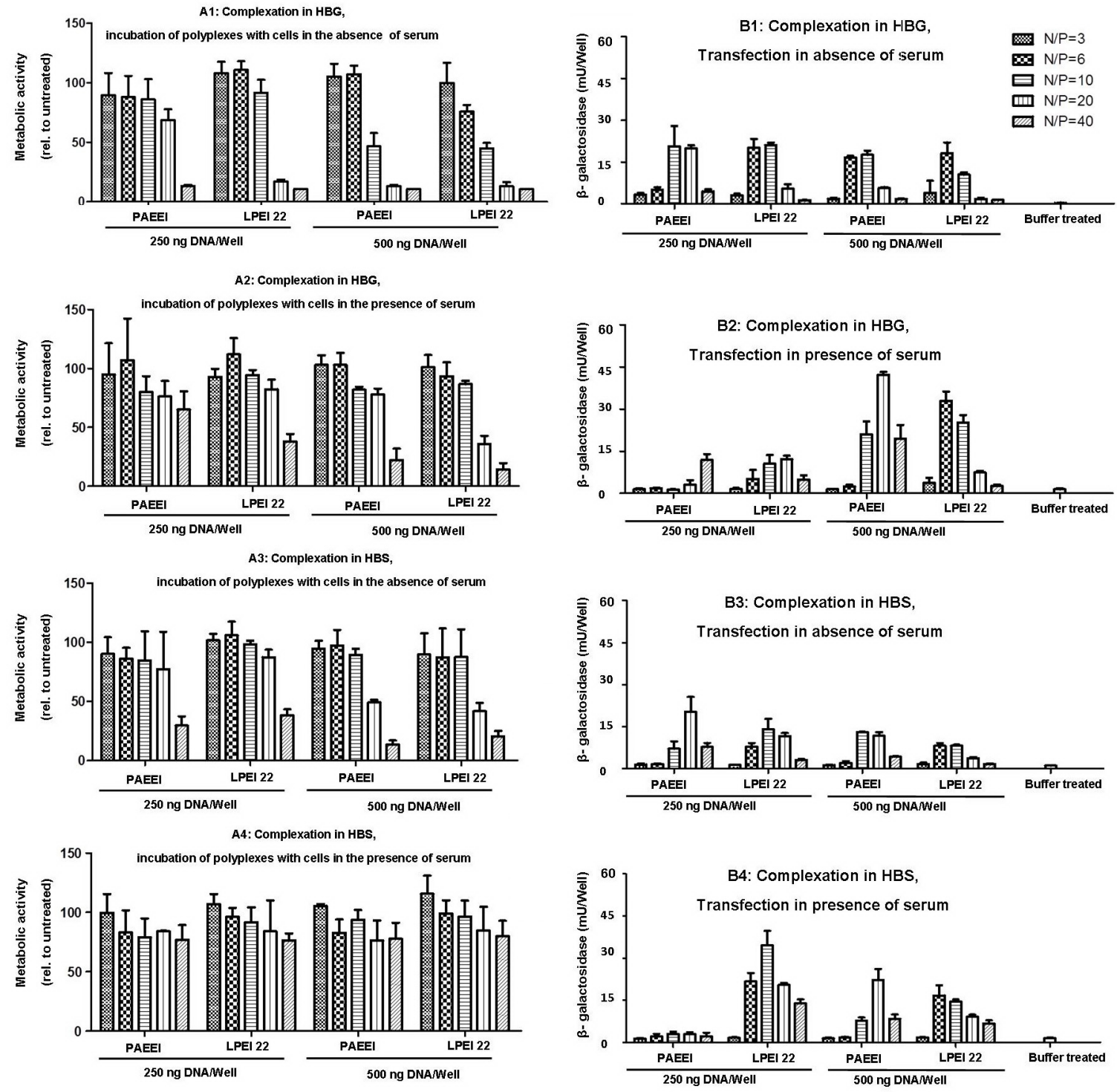

Figure 6. Viability (A) and expression of $\beta$-galactosidase (B) after transfection of HeLa cells with PAEEI polyplexes with 0.25 and $0.5 \mu \mathrm{g}$ DNA per well. Polyplexes were prepared in HBG or HBS. The polyplexes were incubated with the cells in the presence or absence of $10 \%$ FBS. Linear PEI $22 \mathrm{kDa}$ (LPEI 22) polyplexes were used as control. Data are shown as mean $\pm \mathrm{SD}$ of three experiments. 

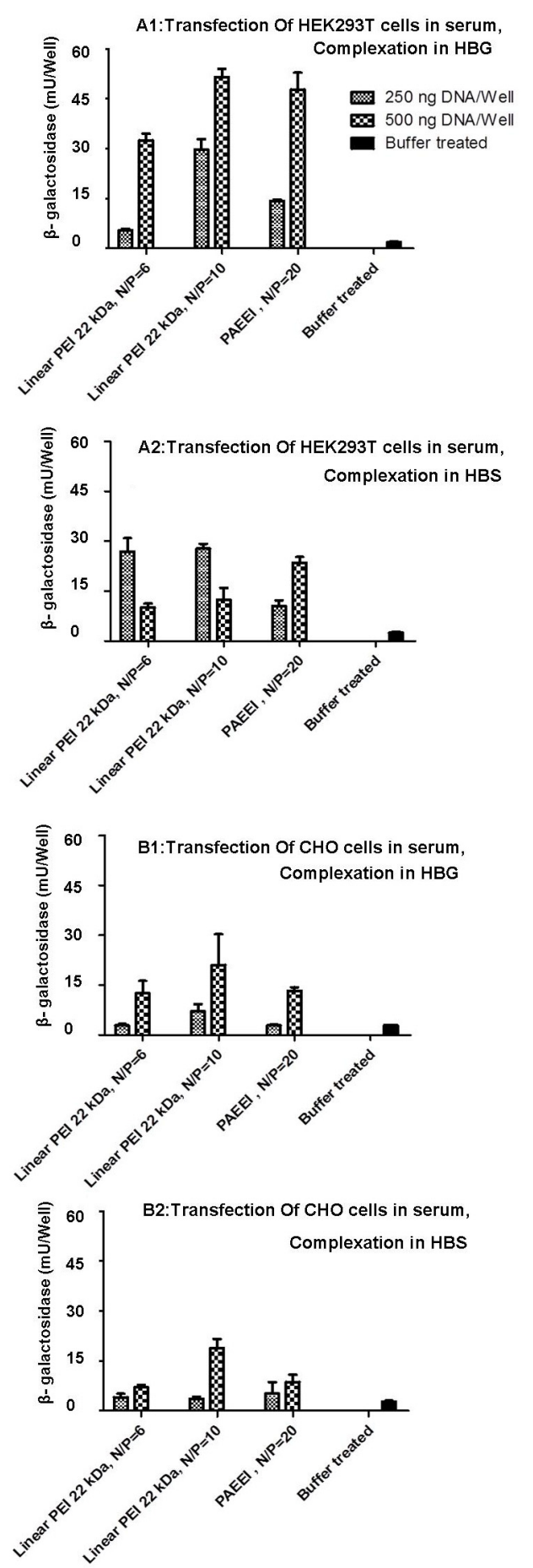

Figure 7. Expression of $\beta$-galactosidase after transfection of HEK293T (A) and CHO (B) cells using PAEEI based polyplexes in the presence of $10 \%$ serum and with 0.25 and $0.5 \mu \mathrm{g}$ DNA per well and $\mathrm{N} / \mathrm{P}$ ratio of 20. Linear PEI $22 \mathrm{kDa}$ polplexes (N/P ratios of 6 and 10) were used as control. Polyplexes were prepared in HBG (A1, B1) and HBS (A2, B2). Data are shown as mean $\pm \mathrm{SD}(\mathrm{n}=3)$.
Polyplexes of PAEEI showed its highest transfection at $\mathrm{N} / \mathrm{P}$ ratio of 20 in most of the experiments. The decrease of transfection efficiency at $\mathrm{N} / \mathrm{P}$ ratio higher than 20 is obviously ascribed to the toxicity of the polyplexes at this concentration (Figure 6). Also, dispersion of PAEEI based polyplexes with a two times higher DNA dose in the same N/P ratio showed transfection activity at the same or even higher extent as compared to polyplexes of lower DNA concentration $(10 \mu \mathrm{g} / \mathrm{mL})$ in HeLa cells (Figure 6B). Moreover, like that of linear PEI, ${ }^{42}$ the polyplexes made with PAEEI showed activity in the presence of serum.

The transfection activity of PAEEI polyplexes was also evaluated in HEK293 T and CHO cells (Figure 7). The transfections were performed in the presence of $10 \%$ serum with polyplexes made in both HBG and HBS buffers. The PAEEI polyplexes prepared in both HBG and HBS buffers displayed comparable transfection activity as linear PEI 22 $\mathrm{kDa}$ systems.

\section{CONCLUSIONS}

The results shown in this paper demonstrate that polyplexes based on PAEEI $10 \mathrm{kDa}$ have similar transfection capability to systems based on linear PEI $22 \mathrm{kDa}$, considered the golden standard of polymeric gene delivery, both in the absence and presence of serum. Taking notice to the fact that the gene delivery efficiency of LPEI molecules with smaller sizes than $22 \mathrm{kDa}$ is less than that of LPEI 22 as the golden standard, it is concluded that higher buffering capacity resulting from more protonatable nitrogen per monomeric unit in PAEEI (twice that of LPEI) compensated the impact of its smaller molecular size on the efficiency of gene delivery. Hence, this polymer which is able to make particles with smaller sizes and higher colloidal stability is an attractive candidate for future in vivo gene delivery studies.

\section{REFERENCES}

1. Gardlík R, Pálffy R, Hodosy J, Lukács J, Turna J, Celec P. Vectors and delivery systems in gene therapy. Med Sci Monit, 2005; 11:RA110-121.

2. Kamimura K, Suda T, Zhang G, Liu D. Advances in gene delivery systems. Pharmaceut Med, 2011; 25:293-306. 
3. Al-Dosari MS, Gao X. Nonviral gene delivery: principle, limitations and recent progress. AAPS J, 2009; 11:671-681.

4. Niidome T, Huang L. Gene therapy progress and prospects: Nonviral vectors. Gene Ther, 2002; 9:1647- 1652 .

5. Advani, SJ., Weichselbaum, RR., Kufe, DW., Gene Delivery Systems. In: Kufe DW, Pollock RE, Weichselbaum RR, et al., (eds). Holland-Frei Cancer Medicine. 6th ed., BC Decker, Hamilton, ON, 2003. Available from: http:/www.ncbi.nlm.nih.gov/books/NBK12776/

6. De Smedt SC, Demeester J, Hennink WE. Cationic Polymer Based Gene Delivery Systems. Pharm Res, 2000; 17:113-126.

7. Park TG, Jeong JH, Kim SW. Current status of polymeric gene delivery systems. Adv Drug Deliv Rev, 2006; 58:467-486.

8. Mintzer MA, Simanek EE. Nonviral vectors for gene delivery. Chem Rev, 2009; 109:259-302.

9. Lutena J, van Nostruma CF, De Smedtb SC, Hennink WE. Biodegradable polymers as non-viral carriers for plasmid DNA delivery. J Control Release, 2007; 126:97-110.

10. Thomas M, Klibanov AM. Non-viral gene therapy: polycation-mediated DNA delivery. Appl Microbiol Biotechnol, 2003; 62:27-34.

11. Putnam D. Polymers for gene delivery across length scales. Nat Mater, 2006; 5:439-451.

12. Khosravi-Darani K, Mozafari MR, Rashidi L, Mohammadi M. Calcium based non-viral gene delivery: an overview of methodology and applications. Acta Med Iran, 2012; 48:133-141.

13. Slowing LL, Vivero-Escoto JL, Wu CW, Lin VS. Mesoporous silica nanoparticles as controlled release drug delivery and gene transfection carriers. Adv Drug Deliv Rev, 60(11):1278-1288.

14. Li W, Szoka FC Jr. 2007; Lipid-based nanoparticles for nucleic acid delivery. Pharm Res, 2008; 24:438449.

15. Balazs DA, Godbey WT. Liposomes for Use in Gene Delivery. J Drug Deliver, (2011), 2011; Article ID 326497, 12 pages, doi:10.1155/2011/326497

16. Martin EM, Rice KG. Peptide-guided gene delivery. AAPS J, 2007; 9:E18-E29.

17. Langlet-Bertin B, Leborgne C, Scherman D, Bechinger B, Mason AJ, Kichler A. Design and evaluation of histidine-rich amphipathic peptides for siRNA delivery. Pharm Res, 2010; 27:1426-1436.

18. Boussif O, Lezoualc'h F, Zanta MA, Mergny MD, Scherman D, Demeneix B, Behr JP. A versatile vector for gene and oligonucleotide transfer into cells in culture and in vivo: polyethylenimine. Proc Natl Acad Sci U S A, 1995; 92:7297-7301.

19. Thomas M, Lu JJ, Ge Q, Zhang C, Chen J, Klibanov AM. Full deacylation of polyethylenimine dramatically boosts its gene delivery efficiency and specificity to mouse lung. Proc Natl Acad Sci U S A, 2005; 102:5679-5684.

20. Godbey WT, Wu K, Mikos AG. Poly(ethylenimine) and its role in gene delivery. J Control Release, 1999; 60:149-160.

21. Fischer D, Bieber T, Li Y, Elsässer HP, Kissel T. A Novel Non-Viral Vector for DNA Delivery Based on Low Molecular Weight, Branched Polyethylenimine: Effect of Molecular Weight on Transfection Efficiency and Cytotoxicity. Pharm Res, 1999; 16:1273-1279.

22. Godbey WT, Wu KK, Mikos AG. Size matters: Molecular weight affects the efficiency of poly(ethylenimine) as a gene delivery vehicle. J Biomed Mater Res, 1999; 45:268-275.

23. Denga R, Yuea Y, Jina F, Chenb Y, Kungb HF, Linc MCM, Wua C. Revisit the complexation of PEI and DNA-How to make low cytotoxic and highly efficient PEI gene transfection non-viral vectors with a controllable chain length and structure? J Control Release, 2009; 140:40-46.

24. Zheng M, Zhong Z, Zhou L, Meng F, Peng R, Zhong Z. Poly(ethylene oxide) grafted with short polyethylenimine gives DNA polyplexes with superior colloidal stability, low cytotoxicity, and potent in vitro gene transfection under serum conditions. Biomacromolecules, 2012; 13:881-888.

25. Merkel OM, Librizzi D, Pfestroff A, Schurrat T, Buyens K, Sanders NN, De Smedt SC, Behe M, Kissel T. Stability of siRNA polyplexes from poly(ethylenimine) and poly(ethylenimine)-gpoly(ethylene glycol) under in vivo conditions: effects on pharmacokinetics and biodistribution measured by Fluorescence Fluctuation Spectroscopy and Single Photon Emission Computed Tomography (SPECT) imaging. J Control Release, 2009; 138:148-159.

26. Kunath K, von Harpe A, Petersen H, Fischer DVoigt $\mathrm{KH}$, Kissel T, Bickel U. The structure of PEGmodified poly(ethylene imines) influences biodistribution and pharmacokinetics of their complexes with NF-kappaB decoy in mice. Pharm Res, 2002; 19:810-817.

27. Merkel O.M, Beyerle A, Librizzi D, Pfestroff A, Behr TM, Sproat B, Barth PJ, Kissel T. Nonviral siRNA delivery to the lung: investigation of PEGPEI polyplexes and their in vivo performance. Mol Pharm, 2009; 6:1246-1260.

28. Schaffert D, Kiss M, Rödl W, Shir A, Levitzki A, Ogris M, Wagner E. Poly(I:C) mediated tumor growth suppression in EGF-receptor overexpressing tumors using EGFpolyethylene glycol-linear polyethylenimine as carrier. Pharm Res, 2001; 28:731-741.

29. Jiang G, Park K, Kim J, Kim KS, Hahn SK. Target Specific Intracellular Delivery of siRNA/PEI-HA 
Complex by Receptor Mediated Endocytosis. Mol Pharm, 2009; 6:727-737.

30. Cheng H, Zhu JL, Zeng X, Jing Y, Zhang XZ, Zhuo RX. 2009; Targeted gene delivery mediated by folate-polyethylenimine-block-poly(ethylene glycol) with receptor selectivity. Bioconjug Chem, 20(3):481-487.

31. Thomas M, Ge Q, Lu JJ, Chen J, Klibanov AM. Cross-linked small polyethylenimines: while still nontoxic, deliver DNA efficiently to mammalian cells in vitro and in vivo.Pharm Res, 2005; 22:373380 .

32. Lemkine GF, Demeneix BA. Polyethylenimines for in vivo gene delivery. Curr Opin Mol Ther, 2001; 3:178-182.

33. Wightman L, Kircheis R, Rössler V, Carotta S, Ruzicka R, Kursa M, Wagner E. Different behavior of branched and linear polyethylenimine for gene delivery in vitro and in vivo. J Gene Med, 2001; 3:362-372.

34. Behr JP. The proton sponge: a trick to enter cells the viruses did not exploit. Chimia, 1997; 51:34-36.

35. Akinc A, Thomas M, Klibanov AM, Langer R. Exploring polyethylenimine-mediated DNA transfection and the proton sponge hypothesis. J Gene Med, 2005; 7:657-663.

36. Fikentscher R, Miksovsky F. 1969; DE 1941175 (BASF Aktiengesellschaft).

37. Koper GJM, van Duijvenbode RC, Stam DDPW, Steuerle U, Borkovec M. Synthesis and Protonation Behavior of Comblike Poly(ethyleneimine). Macromolecules, 2003; 36:2500-2507.

38. Jiang $X$, van der Horst $A$, van Steenbergen MJ, Akeroyd N, van Nostrum CF, Schoenmakers PJ, Hennink WE. Molar-Mass Characterization of Cationic Polymers for Gene Delivery by Aqueous Size-Exclusion Chromatography. Pharm Res, 2006; 23:595-603.

39. van der Aa LJ, Vader P, Storm G, Schiffelers RM, Engbersen JFJ. Optimization of poly(amido amine)s as vectors for siRNA delivery. J Control Release, 2011; 150:177-186.

40. Luo S, Cheng RU, Meng F, PARK TG, Zhong Z. Water Soluble Poly(histamine acrylamide) with Superior Buffer Capacity Mediates Efficient and Nontoxic In Vitro Gene Transfection. J Polym Sci, Part A: Polym Chem, 2011; 49:3366-3373.

41. Morrison, RT.; Boyd, RN., Organic Chemistry. Prentice-Hall, Englewood Cliffs, NJ, USA, 1992.

42. Yang J, Hendricks W, Liu G, McCaffery JM, Kinzler KW, Huso DL, Vogelstein B, Zhou S. A nanoparticle formulation that selectively transfects metastatic tumors in mice. Proc Natl Acad Sci U S A, 2013: 110: 14717-14722.

43. van Gaal EVB, van Eijk R, Oosting R.S,. Jan Kok R,. Hennink WE, Crommelin DJA, Mastrobattista E.
How to screen non-viral gene delivery systems in vitro? J Control Release, 2011; 154:218-232.

44. Delgado AV, Gonzalez-Caballero F, R. J. Hunter RJ, L. K. Koopal LK, Lyklema J. Measurement and interpretation of electrokinetic phenomena. Pure Appl Chem, 2005; 77:1753-1805.

45. Cherng JY, van de Wetering $P$, Talsma $H$, Crommelin DJ, Hennink W. Effect of size and serum proteins on transfection efficiency of poly ((2-dimethylamino)ethyl methacrylate)-plasmid nanoparticles. Pharm Res, 1996; 13:1038-1042.

46. Duan X, Xiao J, Yin Q, Zhang Z, Mao S, Li Y. Amphiphilic graft copolymer based on poly(styreneco-maleic anhydride) with low molecular weight polyethylenimine for efficient gene delivery. Int $\mathrm{J}$ Nanomedicine, 2012; 7:4961-4972.

47. Mann A, Richa R, Ganguli M. DNA condensation by poly-L-lysine at the single molecule level: role of DNA concentration and polymer length. J Control Release, 2008; 125:252-262.

48. Segura T., Formulations and Delivery Limitations of Nucleic-Acid-Based Therapies, in: Gad SC (eds), Hand book of Pharmaceutical Biotechnology. John Wiely \& Sons, INC, Hoboken, NJ, pp 1041-1042, 2007.

49. Lordan, Higginbotham CL. Effect of serum concentration on the cytotoxicity of clay particles. Cell Biol Int, 2012; 36:57-61.

50. Luten J, van Steenis JH, van Someren R, Kemmink J, Schuurmans-Nieuwenbroek NM, Koning GA, Crommelin DJ, van Nostrum CF, Hennink WE. Water-soluble biodegradable cationic polyphosphazenes for gene delivery. J Control Release, 2003; 89:483-497.

51. van de Wetering $\mathrm{P}$, Cherng JY, Talsma $\mathrm{H}$, Crommelin DJ, Hennink WE. 2(Dimethylamino)ethyl methacrylate based (co)polymers as gene transfer agents. J Control Release, 1998; 53:145-153.

52. Brissault B, Kichler A, Guis C, Leborgne C, Danos $\mathrm{O}$, Cheradame H. Synthesis of linear polyethylenimine derivatives for DNA transfection. Bioconjug Chem, 2003; 14:581-587. 


\section{Supporting Information}

Figure 1S illustrates a suggested mechanism for synthesis of N-(2-(1'-aziridino)ethyl)formamide Based on the well-known mechanism of nucleophilic addition (41).

Figure $2 \mathrm{~S}$ depicts the assigned positions of the different peaks of $1 \mathrm{H}$ NMR spectra of the monomer and the polymers. The peaks at 1.3, 1.7 and $2.4 \mathrm{ppm}$ are specific for the monomer. The peaks at 1.3 and $1.7 \mathrm{ppm}$ are assigned to the methylene groups in the ring of aziridine and the peak at $2.4 \mathrm{ppm}$ is related to the methylene group attached to the $\mathrm{N}$ of aziridine out of the ring. Both $\mathrm{N}-\left(2-\left(1^{\prime}\right.\right.$-aziridino)ethyl)formamide and PFEEI show peaks at 8.1 and $3.4 \mathrm{ppm}$, which are assigned to the amide group and the methylene group next to it, respectively. The peak at $2.7 \mathrm{ppm}$, assigned to the methylene groups directly attached to the $\mathrm{N}$ atoms in the backbone, is present in the spectra of both PFEEI and PAEEI. The peak at $2.7 \mathrm{ppm}$ in the spectrum of the monomer is ascribed to the presence of oligomers that are formed either during monomer synthesis or during its purification.

The ${ }^{1} \mathrm{H}$ NMR spectrum of PAEEI obtained after extensive dialysis demonstrates that the amide groups were quantitatively removed by basic hydrolysis because the peak at $8.1 \mathrm{ppm}$, which is assigned to the amide group, is not detected.

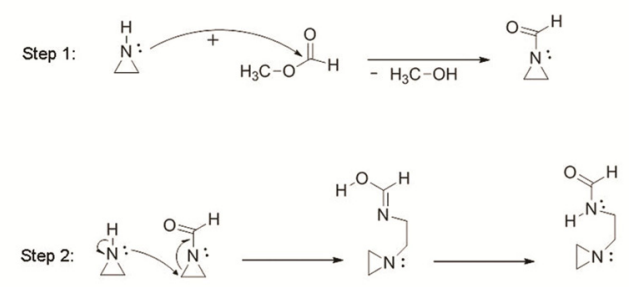

Figure 1S. Suggested mechanism for the synthesis of N-(2-(1'-aziridino)ethyl)formamide. Step 1: Aminolysis of methylformate by aziridine. Step 2: Nucleophilic attack of formylated aziridine.
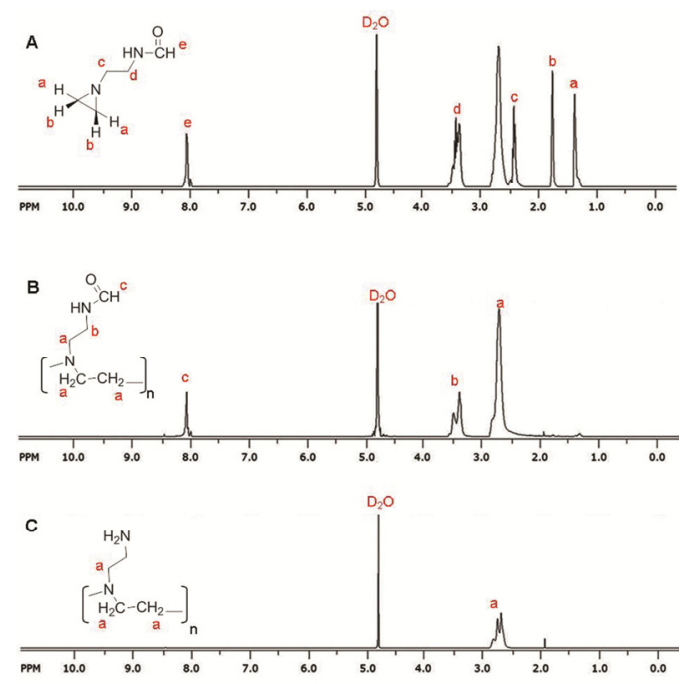

Figure 2S. 1H NMR (300 MHz) Spectra of N-(2-(1'-aziridino)ethyl)formamide, PFEEI and PAEEI in D2O. 